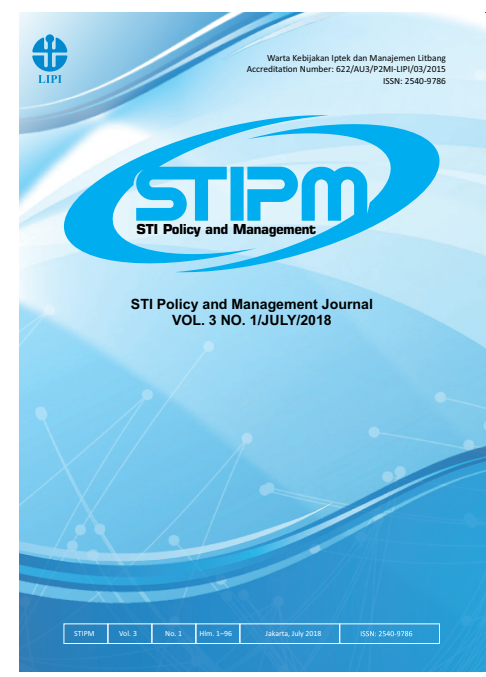

Journal of STI Policy and Management

Publication details, including instructions for authors and subscription information: http://www.stipmjournal.org/

\title{
A Scientometric Study on Biodiesel Development in Indonesia
}

Mesnan Silalahi, Agus Santoso, Dudi Hidayat

Research Center for STI Policy and Management - LIPI

Version of record first published: 15 July 2019

To cite this article: Silalahi, M., Santoso, A., Hidayat, D. (2019). A Scientometric Study on Biodiesel Development in Indonesia. Journal of STI Policy and Management, 4(1), 17-34

To link to this article: http://dx.doi.org/10.14203/STIPM.2019.148

ISSN 2540-9786 (Print); ISSN 2502-5996 (online)

Accreditation Number: 21/E/KPT/2018

Full terms and conditions of use: https://creativecommons.org/licenses/by-nc-sa/4.0/

You are free to:

- Share : copy and redistribute the material in any medium or format

- Adapt : remix, transform, and build upon the material

- The licensor cannot revoke these freedoms as long as you follow the license terms.

Under the following terms:

(1)

Attribution - You must give appropriate credit, provide a link to the license, and indicate if changes were made. You may do so in any reasonable manner, but not in any way that suggests the licensor endorses you or your use.

5. NonCommercial - You may not use the material for commercial purposes.

(2) ShareAlike - If you remix, transform, or build upon the material, you must distribute your contributions under the same license as the original.

No additional restrictions - You may not apply legal terms or technological measures that legally restrict others from doing anything the license permits.

Notices:

- You do not have to comply with the license for elements of the material in the public domain or where your use is permitted by an applicable exception or limitation.

- No warranties are given. The license may not give you all of the permissions necessary for your intended use. For example, other rights such as publicity, privacy, or moral rights may limit how you use the material.

- If you copy the dataset merely to extract the uncopyrightable data elements would not need permission to do so. However, if you republish the full dataset or using the copyrightable data layers require a permission from PAPPIPTEK-LIPI. 


\title{
JOURNAL OF SCIENCE, TECHNOLOGY AND INNOVATION POLICY AND MANAGEMENT (STIPM JOURNAL), Volume 04, Issue 01, July 2019
}

\author{
FOREWORD by EDITOR-in-CHIEF
}

We are very pleased to inform the readers that Journal of Science, Technology, \& Innovation Policy and Management (STIPM Journal) Vol. 4, No. 1, July 2019 edition is now ready for public reading and views. STIPM Journal is an online research journal managed by the Research Center for Science, Technology, and Innovation Policy and Management, Indonesian Institute of Sciences (RC-STIPM-LIPI).

The journal provides scientific information that needed mostly by the research scholars as well as STI policy makers. As a peer reviewed journal, STIPM provides free access to research thoughts, innovation, and original discoveries. In this issue, we bring together research findings on development and adoptation of science, technology, and innovation policy and management from Malaysia and Indonesia.

First article is composed by Wati HERMAWATI entitled Technology Transfer from Public Research Institute to Community: A Case Study. This research article examines the technology transfer mechanisms into practical applications of the community. The success of technology transfer to community itself were demonstrated by the increased ability of recipients namely SMEs and farmers to replicate the technologies, increased their production, enlarge their market as well as increased new knowledge, skills, and productivity.

Second research article entitled A Scientometric Study on Biodiesel Development in Indonesia. This article is presented by Mesnan SILALAHI et al. The article describes the results of scientometric studies in the energy sector, especially in the field of biodiesel in Indonesia by using a mixed method through content analysis and in-depth interview. Quantitative research uses bibliometric basics and content analysis, where text mining is triangulated with the results from in-depth interview with several prominent Indonesian researchers in this field. Content analysis is conducted by topic modeling method by analysing the papers' abstract. This article reports on the results of a scientometric study, based on publications indexed in Scopus in the energy sector, especially in the field of biodiesel in Indonesia.

Nor Ashikin Mohamed YUSOF et al. present an article entitled Theoretical and Practical Gaps in Policy Making Process in Five Organizations. This article reports case studies involving five national policy documents and internal policies at several key governmental department and organizations. The findings from the study enables the researchers to make a comparison between the theory of policy making and the practice of policy making in Malaysia. The findings show that there is still a huge gap between theory and practice in policy making and policy studies in Malaysia.

The fourth article with the title Innovative Strategy to Disseminate Science Information to Policy makers is presented by Azmi HASSAN. There exists a huge gap between science and technology discovery and the formulation of public policy mostly due to the poor understanding on how to disseminate the 
news not only to policy makers but also to the general public. To bring accurate, relevant information from the front lines of research to the policy makers, this paper describes how innovative strategies that use the media as the conduit are formulated in more systematic ways.

Dian KUSUMANINGRUM et al. present an article entitled Structural Equation Model: Intention to Use Mobile Banking of Bottom of Pyramid Customer. The purposes of the study are to identify the predicting factors influencing the intention to use mobile banking and empirically validate a model explaining the behavioral intention to use it, especially on the bottom of pyramid (BOP) segment. The model used was structural equation model (SEM) based on partial least square (PLS). The data used for developing the model was based on a survey to 100 BOP households. The results show that the variables that have the highest significant effect on BOP's customer intention to use mobile banking are involuntary barriers, followed by perceived risk, and attitude. This result can be further used by researchers and mobile banking providers to evaluate the existing mobile banking services to improve its contribution in providing better market penetration and more appropriate financial services for BOP and ultimately financial inclusion in Indonesia.

Lastly, Karlina SARI et al. present an article entitled Indonesia in Functional Food Industry: Market or Player? This paper presents the overview of functional food industry in Indonesia. It analyzes the prospect of Indonesian functional food industry from demand, supply, and regulation perspective. The result of this study is Indonesia should have a good prospect as both the market and the player in functional food industry. Currently, baby food and toddler are Indonesia's biggest market of functional food for baby formula milk and baby food. Another functional food market segment prospective to be penetrated is elderly who have bigger risk of disease, such as hypertension and arthritis

The journal is indexed by Google Scholar, ISJD, IPI, DOAJ, BASE, and OCLC World Cat, which makes wider journal dissemination. We would like to express our immense gratitude to our international editorial board members, reviewers, and authors for their contribution to this issue. We hope this publication will prove useful for readers and contribute to the enhancement of science, technology, and innovation. We expect that STIPM will always provide a higher scientific platform for authors and readers with a comprehensive overview of the most recent STI Policy and Management research and development at the national, regional, dan international level.

Jakarta, July 2019

Editor-In-Chief 



\section{JOURNAL OF STI POLICY AND MANAGEMENT}

Volume 4, Number 1, July 2019

\section{LIST OF CONTENTS}

Technology Transfer from Public Research Institute to Community: A Case Study

Wati Hermawati.

A Scientometric Study on Biodiesel Development in Indonesia

Mesnan Silalahi, Agus Santoso, Dudi Hidayat

Theoretical and Practical Gaps in Policy Making Process in Five Organizations

Nor Ashikin Mohamed Yusof, Sri Widias Asnam, Aini Suzila Anas, Nur Suraya Mustapha,

Natrah Emran, Nor Azalina Azman

Innovative Strategy to Disseminate Science Information to Policy Makers

Azmi Hassan

Bottom of Pyramid Customer Intention to Use Mobile Banking: Structural Equation Model

Dian Kusumaningrum, Dewi Saraswati, Seprianus.

Drivers of Industry Convergence: The Case of Functional Food Industry in Indonesia

Karlina Sari, Dian Prihadyanti, Dudi Hidayat 


\title{
in STI POLICY AND MANAGEMENT \\ LIPI Journal homepage: http://www.stipmjournal.org
}

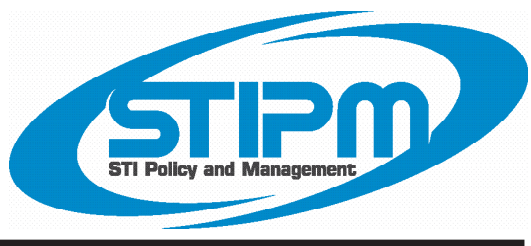

\section{A Scientometric Study on Biodiesel Development in Indonesia}

\author{
Mesnan Silalahi, Agus Santoso, Dudi Hidayat \\ Research Center for STI Policy and Management - LIPI \\ mesnans@yahoo.com
}

\begin{tabular}{|c|c|}
\hline ARTICLE INFO & ABSTRACT \\
\hline $\begin{array}{l}\text { Article History: } \\
\text { Received : } 05 \text { November } 2018 \\
\text { Revised : } 27 \text { June } 2019 \\
\text { Accepted : } 28 \text { June } 2019 \\
\text { Available online : } 15 \text { July } 2019\end{array}$ & $\begin{array}{l}\text { This paper describes the results of scientometric studies in the } \\
\text { energy sector, especially in the field of biodiesel in Indonesia using } \\
\text { a mixed method through content analysis and in-depth interview. } \\
\text { Quantitative research uses bibliometric basics and content analysis, } \\
\text { where text mining is triangulated with the results from in-depth }\end{array}$ \\
\hline $\begin{array}{l}\text { Keywords: } \\
\text { Scientometrics } \\
\text { Indonesia } \\
\text { Biodiesel } \\
\text { Citation analysis } \\
\text { Co-Authorship analysis } \\
\text { Co-Word analysis } \\
\text { Topic modelling } \\
\text { Social network analysis }\end{array}$ & $\begin{array}{l}\text { interview with several prominent Indonesian researchers in this field. } \\
\text { Content analysis is conducted by topic modeling method using some } \\
\text { papers' abstracts. This article reports on the results of a scientometric } \\
\text { study, based on publications indexed in Scopus' energy section, } \\
\text { particularly biodiesel in Indonesia. The mixed method gave a deep } \\
\text { view or a rich picture of some interesting findings of the quantitative } \\
\text { analysis. The study is expected to provide recommendations in } \\
\text { national priority program for energy research policies and strategies. } \\
\text { C2019 PAPPIPTEK-LIPI All rights reserved }\end{array}$ \\
\hline
\end{tabular}

\section{A. INTRODUCTION}

Agenda in the development of the world energy industry, as in the 2016 World Energy Scenario World Energy Forum Report (Figure 1), states the decarbonisation of energy as the biggest single driver behind the global agenda in the energy transition. Renewable energy and energy efficiency count for the highest concerns along with electricity prices and energy subsidies. Also, electric storage also has a high impact with high uncertainty. Advances in electric storage and renewable energy are key areas that have the potential to dictate the energy transition in the future. Globally, the development impact in the solar and wind energy industry is increasing, whereas biodiesel industry is still rated as low-impact and a non-carbon neutral solution. Nevertheless, from Indonesia's perspective, biodiesel is playing an important role and has a high potential impact for the economy of the country.

In Indonesia, the economic agenda is to accomplish an economic independency by driving the domestic economic strategic sector. One of the goals is to realize energy independency. To this end, the government builds several national priorities in energy sector, one of them is an energy mix through the development of renewable energy (RE). In 2016, RE contributed 3.3\% of primary energy and to achieve the $23 \%$ target by 2025 , the government must make a breakthrough in innovation and issues regulations that are consistent, measurable and investment-friendly. Indonesian biodiesel has a potential contribution to world energy availability (Figure 2). Indonesia has a huge potential because it has natural resources to make it happen, one of them is oil palm. The idea of oil palm as renewable energy 
THE FUTURE ENERGY LEADERS' AGENDA

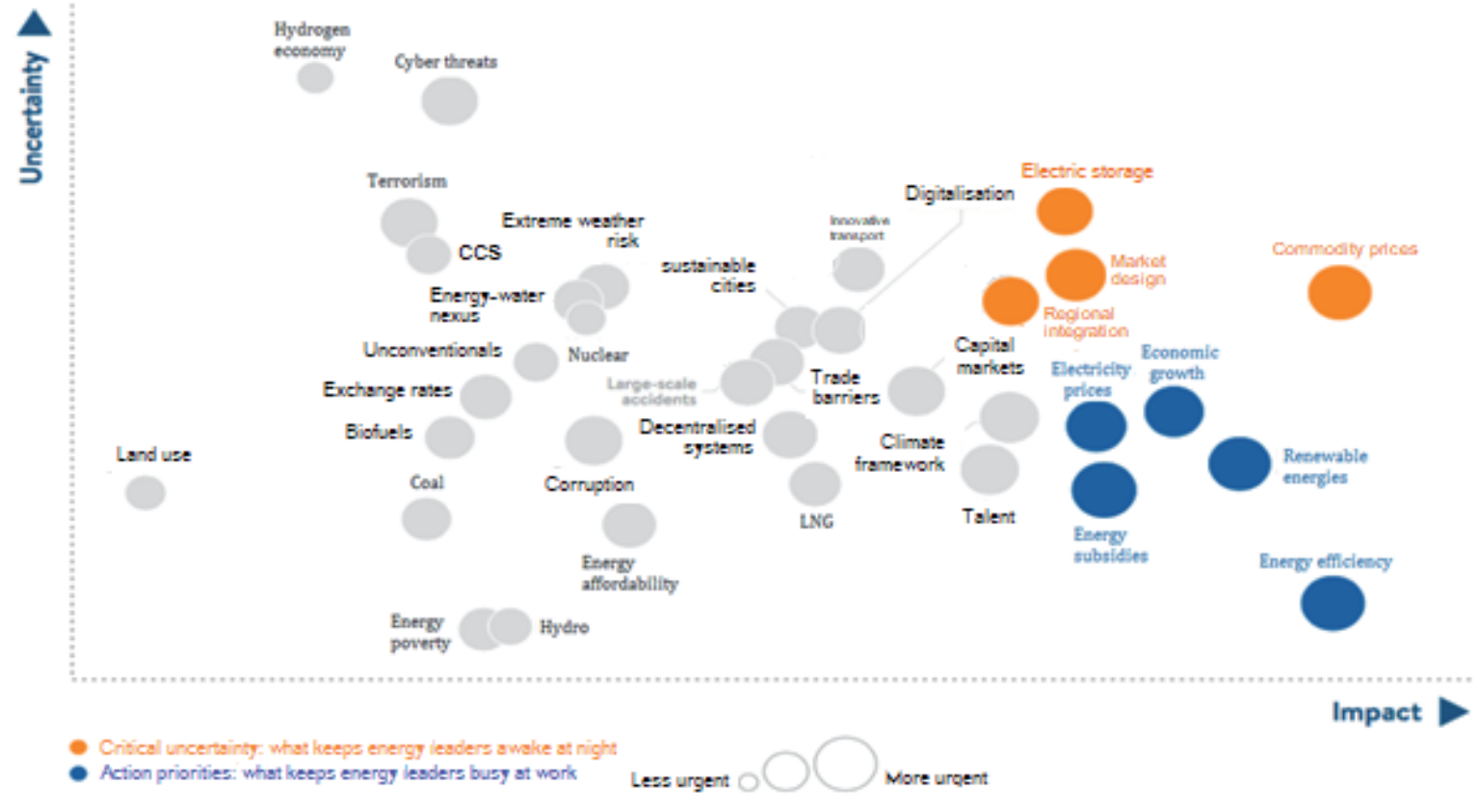

Source: World Energy Council Report (2017)

Figure 1. Adapted World Energy Scenario

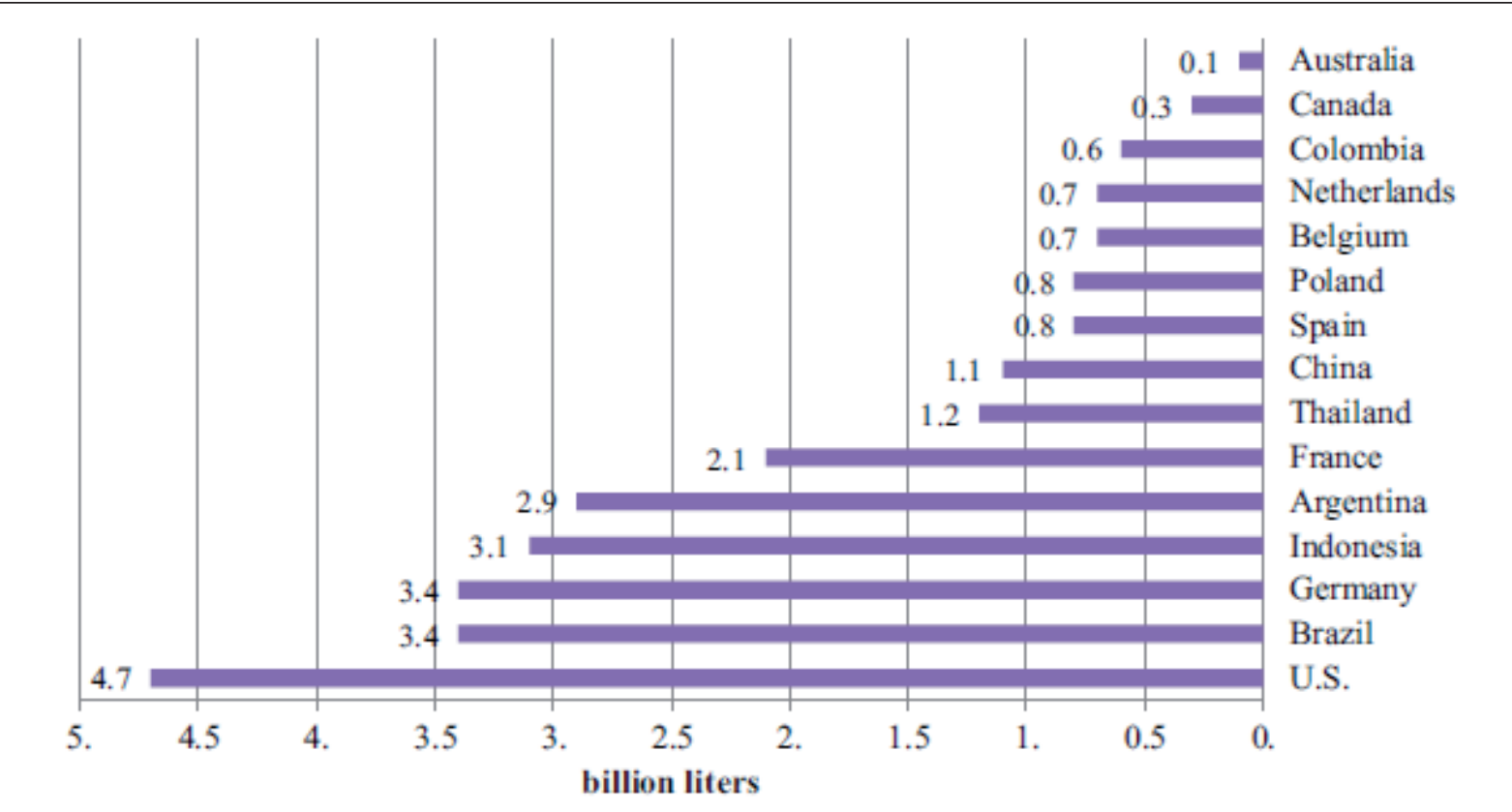

Source: REN21 (2015)

Figure 2. World's Biggest Biodiesel Producers in 2014

is a bit hung up as most other countries are still using biodiesel, especially for transportation. It is still held back by sustainability debates, policy uncertainty and slow technological progress in advanced fuels, for example jet fuel in aviation industry (REN21, 2018).
To ensure sustainability of the inovation based biodiesel energy industry, it is necessary to boost the productivity and quality of national research especially in biodiesel, for example through a better efficiency in the transesterification process, a new membrane technology 
(chemical processing), a supercritial processing technology, or a new alternative of feedstock for biodiesel like microalgae. Research should provide an input for the assesment of future technology development in energy sector suitable for Indonesia. For sustainability in coal-based power generation, Sambodo, Morohosi, and Oyama (2016) argues that Indonesia needed to pursue technology to switch from steam coal subcritical technology to supercritical and ultra-supercritical technology to reduce $\mathrm{CO}_{2}$ emissions. One way to improve Indonesia's technology competitiveness is to measure the development of research. National scientific publication data of researches in the energy domain has developed in significant numbers, so that it can be used as an analytical tool to provide an overview of the science and technology development in Indonesia's sector in Indonesia. The development of science and technology is the basis for innovation. Scopus database, as of May 2018, recorded a breakdown of 64,502 affiliated Indonesian publications according to subject areas are detailed in Table 1 below.

Table 1. Indonesian Research Publication in Scopus

\begin{tabular}{lc}
\hline \multicolumn{1}{c}{ Subject } & \#Publication \\
\hline Engineering & 17,947 \\
\hline Computer Science & 12,154 \\
\hline Physics and Astronomy & 9,423 \\
\hline Agricultural and Biological Sciences & 8,626 \\
\hline Environmental Science & 7,264 \\
\hline Social Sciences & 7,012 \\
\hline Medicine & 6,431 \\
\hline Materials Science & 5,360 \\
\hline Mathematics & 4,495 \\
\hline Earth and Planetary Sciences & 4,221 \\
\hline Total & 64,502 \\
\hline
\end{tabular}

\section{B. LITERATURE REVIEW}

Based on Table 1, most of Indonesian publications' subjects in Scopus focus on engineering and most of energy research publications can be found in engineering areas and material science. It means that the amount of those publications can be used as data source to analyze the science and technology development in Indonesia. Results analysis of these studies in Indonesia has never been carried out using scientometric studies. Moreover, richer textual information stored in scientific documents has never been analyzed. To this end, a scientometric study was conducted including the textual content of scientific publications in the Indonesian energy sector. According to Van Raan (1997), scientometrics can be defined as a quantitative study of science and technology. Bibliometric research can be used to study the knowledge progress in science and technology development in relation to social and policy problems (Van Raan, 1997). Some methods include citation analysis to analyze impact assessment and research performance, while co-word analysis is to map science and to produce visualizations of science (Van Raan, 2014). Policy formulation in science requires evidence as a basis. For this reason, it is necessary to conduct scientometric studies based on reliable data sources. Content analysis using text mining is needed to provide contextual insight into science development in a domain by processing specific textual information and other information as evidence. Text processing allows the extraction of elements that enrich the semantic value in data analysis for the purpose of analysis toward the rhetoric of scientific discourse, methodological descriptions and so on. To be able to find out the thematic composition of large document collections, researchers start using quantitative topic modeling. Among the developed various ways, the most prominent was Latent Dirichlet Allocation (LDA) (Blei, Ng, \& Jordan, 2003). The application of LDA in topic modeling can reveal the distribution of topics in each document in the corpus.

Scientometrics is used to understand the research structure and development by analyzing the publications to find out the patterns related to co-authorship, institutional relations and categorical patterns in energy research as well as providing alternative research advancements, which can be potential knowledge. Research output measurement through scientometrics can be in the form of studying the characteristics and changes in world trends or major countries, with a special focus on publications. The output can be used as an indicator of science and technology research. Another output indicator is the relation- 
ship between input and output of the scientific production publications in research institutions and universities. Individual and aggregated indicators were used to compare the interested field situation in Indonesia and regional or influencing countries.

de Souza, de Morales, Poz, and da Silveira (2015) used aggregate values, such as average centrality degree, average density and average geodesic distance, as a measure of development degree of the innovation system in lignocellulosic ethanol between countries. So far, there has been no research in energy domains in scientometrics that focuses on condition in Indonesia. Meanwhile, several studies (Silalahi et al., 2018a; Silalahi et al., 2018b; Hardiyati, Nadhiroh, Handayani, Silalahi, Rahmaida, \& Amelia, 2018) have been pursued to build competence in conducting Indonesian scientometric studies. The studies used complementary text analytics in content analysis of scientific articles which provide insight into the research and bring new perspectives to understanding content.

\section{Research Trend Analysis}

In Wordnet dictionary, the definition of trend analysis in general is the analysis of changes over time. Trend analysis often referring to techniques in statistics for extracting an underlying pattern of behavior that would otherwise be partly or almost completely hidden. Analysing trend using text can be done by word usage, how words change in the frequency of use in time (diachronic analysis), in order to find neologisms or archaisms (Costin-Gabriel \& Rebedea, 2014). The development trend, in a given field of research, is very important in influencing the decision on R\&D funding (Sitarz, 2013). Research funding decisions are difficult because of the exponential growth in the number of publications. The discovery of knowledge hidden in the huge collection of publications in a database opens up new fields of research, but the prediction of its success and making such research funding decisions is very difficult. Forecasting the progress in developing field of research seems less risky than examining newly discovered topics. In known research fields, it is possible to identify research trends that allow forecasting future characteristics. The research trend analysis is generally carried out by looking at the publication activity presentation as the change in the number of publications over time. This approach, however, has a weakness due to exponential publication growth. Therefore, it must be strived to look at the trend in other ways that are more accurate.

New technology makes the research cycle even shorter to the industrial stage. This requires careful analysis of current research trends. The development of research fields is estimated by the analysis of past publication activities and dynamic changes. The number of publications is a good measure of research intensity (Tsai, 2011). However, changes in the number of publications from time to time must be taken into account in forecasting future developments. Structuring research and technological knowledge and dynamics analysis are not a trivial task. Assessment of the research subject development depends on time evolution from the distribution of both citation and co-citation or the number of publications. Because these values grow exponentially, this approach does not adequately reflect the development of the analyzed research subjects. The assumption that the number of publications represents thematic development status is doubtful because the exponentially growing volume makes it more difficult to filter qualifications and identify actual trends (Sitarz, 2013).

\section{2. h-Index}

The total number of citations, as a metric, is strongly influenced by the number of publications, thus neither provides information about the productivity nor sensitivity to productivity. Hirsch (2005) proposed a combined number of impacts (citations) and productivity (articles) into one single measure called h-index. It is defined as a scholar with an index of $\mathrm{h}$ who has published $h$ papers each of which has been cited in other papers at least $h$ times. This index combines both the number of citations and the number of papers. The h-index ignores all other publications under the citations, and it also ignores the number of citations received above $h$. The advantage is that it is a combination of productivity and impact in 
a single index that is easy to understand and very intuitive and easy to calculate by knowing the number of citations from Web of Science, Scopus or Google Scholar.

\section{Co-word Analysis}

The co-word method analyzes how specific words occur together. This means that groups are defined by a collection of words found in analyzed documents (Yoon, 2008). This method assumes each document as a bag of words and that the words found in scientific papers reflect its contents (Larsen, 2008). Here, a vector of words is found in the document analyzed or a matrix of the vector (vector space model). Some of them are only based on previously selected keywords, so it's easy to create vectors. In practice, most of methods mine the words in titles and abstracts, but some of them mine the words in full text. For general purposes, it is necessary to choose informative words as a good discriminator. One of the most commonly used inputs in the statistical processing is the term frequency inverse document frequency (TF-IDF) value which can be calculated by the formula given in (Manning, Raghavan, \& Schütze, 2007). This value is high for many words in a small number of documents. This coefficient is small when a rare or everpresent word emerges. Therefore, the higher the TF-IDF, the more discriminatory a word is.

\section{Social Network Analysis}

Social network analysis (SNA) is a method commonly used in bibliometrics for collaboration analysis in scientific publications. It allows us to identify the main clusters (working groups) and networks that are actively producing scientific information, going beyond the existing formal structures for cooperation, thereby enabling the characterization of their scientific activity. It also provides information that may be useful for assessing the collaboration degree between authors and may lead to closer integration of the groups. The centrality indicator according to Freeman (1978/79) is defined in three ways, degree, closeness, and betweenness. Degree is to measures the level of communicative activity (the capacity to communicate directly with others) and closeness is to measures independence (the capacity to reach many of the other members of the network directly, i.e. without relying on intermediaries). Betweenness is the frequency with which a node appears in the shortest path (geodesic) that connects two others, and it can be interpreted as the control authors exert over communication between others and their capacity to restrict it. It measures the informal power and gate keeping to the network.

\section{Topic Modeling}

The measurement of the impact of a research publication provides a useful complement to building policies in research management. Bibliometric indicators have been widely studied, especially in journal context. However, journal-based bibliometric metrics do not capture topical differences in fast-moving fields and this is increasingly revealed with the emergence of open access publishing. More in-depth analysis on the content had also been pursued for comprehensiveness. Mao, Zou, Chen, Du, and Zuo (2015) conducted a bibliometric study on biomass energy research by applying a content analysis based on the key words and titles of publications in order to identify the hot spots of research in a specific field. This technique still has very limited information in terms of the content analysis. Other methods based on co-word analysis are not ideal because they do not provide identification of topics from the groups produced. Documents can only be given to one cluster, which assumes a monothematic character from each publication. The assumption used in topic modeling is that each publication is rarely monothematic and usually addresses many topics (MacRoberts \& MacRoberts, 1996).

The probabilistic topic model is a set of algorithms whose purpose is to find thematic structures hidden in large document archives (Blei, 2012). LDA (Latent Dirichlet Allocation) is a generic probabilistic model whose basic idea is that documents can be represented as weighted vectors on latent topics, where topics are characterized by the distribution of words. This model can reveal the main themes of the corpus that can potentially be used to organize search and explore corpus documents. By revealing the main themes, 
the latest research in scientometric studies uses this model to uncover new knowledge that can be used to build new indicators. The evaluation of the quality of the topic modeling is carried out through quantitative and qualitative approach. The qualitative approach is to evaluate the topics on their human interpretability by presenting them to humans. The quantitative setup is using a procedure which searches for the parameters that minimize the model's perplexity on held-out data. The lowest perplexity score usually offers meaningful and interpretable topics. Although the perplexity-based method may generate meaningful results in some cases, it is not stable. Zhao, Chen, Perkins, Liu, Ge, Ding, and Zou (2015) conducted a heuristic investigation to get a meaningful results for the purpose of a study or task. Chang, Gerrish, Wang, Boyd-graber, \& Blei (2009) showed that human interpretation can be slightly anti correlated with the result from a perplexity evaluation.

\section{METHODOLOGY}

This research is a descriptive study of the development of research in the energy sector that uses a mixed method in its operationalization. In the quantitative data analysis, the investigation is limited to the Scopus database as a data source from the year 2000 to present (2019). Other sources of information are not regarded because the time and resource constraint of the research. Meanwhile, the qualitative approach was carried out by in-depth interviews with experts or authors (researchers) in related fields whose significant publications were indexed by Scopus. The general goal is to get a rich description as a complement to the interpretation of the quantitative data analysis and in exploring issues and contexts related to the development of science and technology in the energy sector in Indonesia.

This study began with a literature study related to the topic of biodiesel research in Indonesia. Simultaneously, initial data was collected as input material to determine the research focus. Then, interviews were conducted with domain experts in Indonesia to get an overview of the issues and topics on research in energy in Indonesia. After intensive data collection, analyzes were carried out bibliometrically and then the research content. Content analysis was carried out using topic modeling method which began with the data preprocessing of the text from the abstract and the title. The pre-process includes the tokenisation, stopwords removal, and filtering. The analysis was carried out by looking at the labeling of useful topics and giving meaning and trends in topic development. These results were then clarified by interviewing several prominent Indonesian researchers in the field of biodiesel indexed by Scopus, namely Dr. Robert Manurung, who is also an energy expert in Indonesia, Dr. Arridina Silitonga and Dr. Renita Manurung. The results of quantitative data analysis and qualitative data were then triangulated.

The analysis was conducted at three levels, e.g. micro, meso, and macro level. Measurement at the micro level looked at performance comparisons among top researchers in and out the country. Several indicators used to measure research output with bibiliometric databases were total number of publications, number of publication citations, number of international collaboration publications, and h-index. By obtaining this data, we measured the contribution of Indonesian research output in mapping globally. We used h-index measurements to measure the impact and contribution of research publications on the total number of publications. In international collaborative research publications, the measurement of the number of publications in the category of first authors (first authorship) needs to be considered because the accumulation of great knowledge is in the first author. Measurement at the institutional level was carried out by comparing the performance of the top 10 institutions that contribute to international publications. Comparison was carried out by looking at several indicators, such as total number of publications, number of citations per publication, number of international collaboration publications, and h-index. Measurement at the country level is carried out by comparing research performance in international publications with several comparable countries for competitiveness analysis both at the regional level (by comparison with Malaysia) and at the global level (Brazil, India, and China). Comparison is carried out by looking at several indicators, such as total number 
of publications, number of citations, research topic development or publication content, and energy research social network.

\section{Data Acquisition}

In quantitative data analysis, the Scopus database is used as a data source of publications related to Indonesia from 2000 to present (May 2019) in the field of biodiesel. The keywords used in the search were "biodiesel". It is very important to attach a great attention in the use of the search term. Ho (2018) criticized Mao, Zou, Chen, Du, \& Zuo (2015) for the inappropriate use of search filters that have enormous effects on the results obtained. The Scopus database is international publications database with a broad scope, mainly in technical and engineering fields, that include journals and proceedings from both developed and developing countries. By using the Scopus database, it is expected to provide reliable data related to Indonesian science and technology development, and in comparative analysis at the micro, meso and macro level. Another reason of using it is because of the limited resources for the research. For a scientometric study to be successful, there must be a comprehensive and accurate source of publication and citation data. The main source of citation in the past was Thomson Reuters ISI Web of Science (WoS) which is a special database that includes all the papers from about 12,000 journals which also include conferences and books. However, a very similar competitor database is available, Scopus, which includes 20,000 journals, conferences and books. Both of these databases have become traditional sources for most scientometric studies. The coverage of WoS is natural sciences, social sciences, arts and humanities. In contrast to WoS, the coverage of the new alternative, Google Scholar, is generally higher but the reliability and quality of the data can be uncertain (Amara \& Landry, 2012).

\section{Result Evaluation and Interpretation}

After data processing, the next step was to confirm the information obtained through interviews with researchers where these experts were expected to provide an interpretation of the results from the quantitative analysis data and validate a proposed model that is developed. The results of the discussion were expected to contribute to building better policy recommendations in the future. The risk factors of this study included data analysis (the amount of accessed and collected documents) as well as tools for content analysis, but the available device is an English based preprocessing device. For optimal results, it is also necessary to combine the data from the Google Scholar database. However, due to limited research resources, this research had its limitations.

\section{RESULTS}

In this section, we will describe some findings from the analysis using Scopus indexed publications of Indonesian research in biodiesel. The analysis is carried out in the macro, meso as well as in the micro level. Also, some of the qualitative data from in-depth intervies is presented as a triangulation to support the conclusion.

\section{Macro Level Analysis}

Publication productivity of Indonesian researchers in biodiesel field globally is still significant, but regionally compared to Malaysia, Indonesia was lagging behind both in terms of productivity and its impact (Figure 3). This comparison was taken because the two countries are the largest crude palm oil (CPO) producers in the world.

The issue on energy efficiency will have a big impact on the world's energy industry in

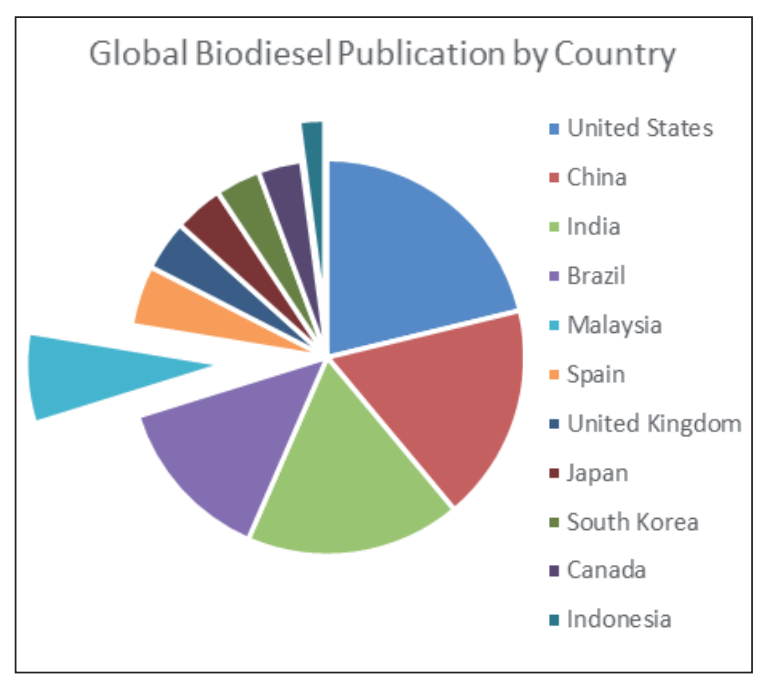

Figure 3. Global Biodiesel Publication in Scopus 
the future (Figure 1). The preliminary analysis shows a weak anticipation in term of $R \& D$ in Indonesia to be competitive in future competition. China imports CPO from Indonesia, but with its technology, China can store its CPO needs for the next 10 years allowing buffering for diverse needs strategically. The capability needs to be pursued to ensure the energy sovereignty of a country. As we know, Indonesian CPO export is often being undervalued because of our inability to process $\mathrm{CPO}$ into derivative products. The industry is often undervalued because the dominant production of our palm oil is exported in the form of CPO, while neighboring country, Malaysia, processes its CPO domestically (product diversification). As we know the most use of world CPO is for surfactants. The existence of government policies that should favor our $\mathrm{CPO}$ could used to produce biodiesel and other products if necessary. In fact, today our $\mathrm{CPO}$ is bigger than that exported. There is uncertainty in the policy that requires the use of biodiesel in the fuel blends that has impacts on the higher biodiesel production in Indonesia. Many biodiesel industries in Indonesia are closed. Therefore, the key is to provide subsidies to the industry in $\mathrm{CPO}$ raw materials as well as the government policy that regulates the use of biodiesel. In September 2018, the government issued a new mandate for the $\mathrm{B} 20$. The $\mathrm{B} 20$ program makes it mandatory for all vehicles to use biodiesel that consists of 20 percent biodiesel and 80 percent petroleum diesel. This mandate is issued after
Indonesia's trade deficit and current account deficit and also as a solution of the export barriers to EU countries. The neighbour countries such as the Philippines has targeted biodiesel blend to be increased to $10 \%$ by 2020 as mandated by RA 9367. Actually, the biodiesel designation is not for the wider community, but for industry applications. Uncertainty in policies will have an implication that the future direction is not clear and without a specific policy framework technological expansion at a meaningful scale is unlikely. Brazil and America produce biodiesel from corn and soybean that disrupts milk consumption, but with a new policy the R\&D strategy will shift to developing microalgae-based biodiesel, so that it does not conflict with FAO recommendations.

Indonesia is still lagging behind Malaysia in the development of palm oil-based industries, for example in the olefin producing technology, although historically Indonesia has been researching biodiesel earlier than Malaysia. The publications of Indonesia in the area of biodiesel began to be indexed by Scopus in 2010, with 24 publications, where the productivity of publications produced until 2018 is far behind the productivity of Malaysian researchers with a factor of three (Figure 4). This can be a proxy to illustrate the primacy of Malaysian biodiesel in terms of technology.

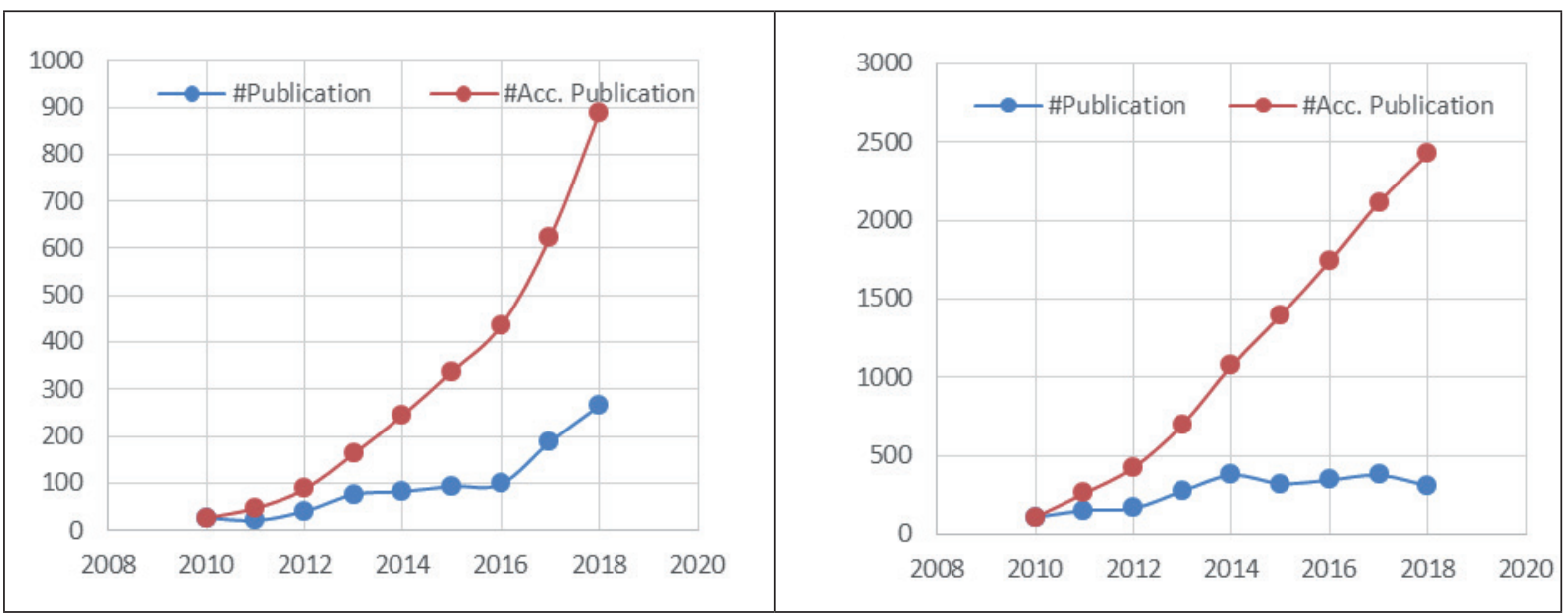

(a) Indonesia

(b) Malaysia

Figure 4. The Comparison between Indonesian and Malaysian Biodiesel Publication in Scopus 


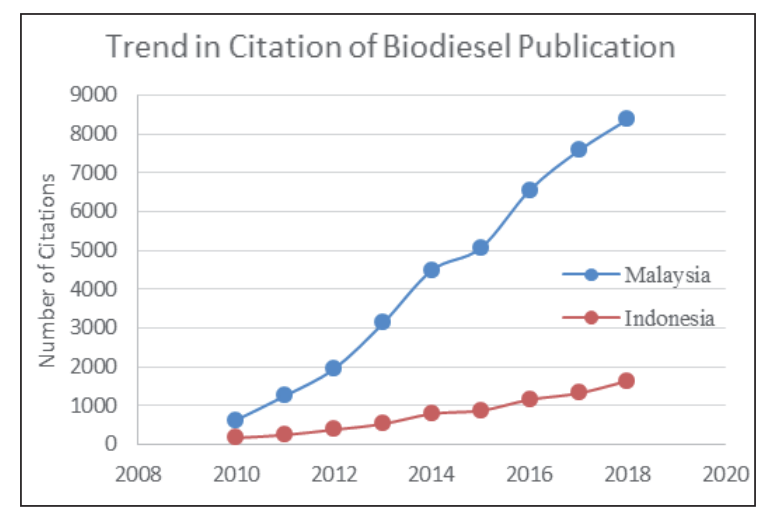

Figure 5. The Comparison between Indonesian and Malaysian Citation on Biodiesel Publication in Scopus

Figure 5 illustrates the result from the publications impact measurement (number of citations) that shows a steady increase since 2010 of Indonesian as well as Malaysian biodiesel research, whereby the Indonesia's curve shows an exponential growth. In comparing Malaysian and Indonesian research quality using the citation's numbers as a proxy, Malaysia also excelled Indonesia. Nevertheles, this statement is not justified without further investigations using various metrics. Interestingly, the citation growth rate of Malaysian research publication shows a slower (almost twice) in 2015. This may happen because the stagnant increase in the number of publications by year since 2014 (Figure 4). It is much more interesting to see the trends between the two countries in the future, as Indonesian government, since late 2018, mandates the use of biodiesel in the fuel blends for transportation which presumably will motivate higher research intensity.

In social network context, Malaysian researchers shows strong social networks compared to Indonesian whose connectivity has begun to develop as visually depicted in Figure 6. In Indonesian researchers' social networks, most of the clusters are still isolated from each other. Collaboration in research has a strong influence on performance in the aggregate. This gap needs attention in the development of future research funding policies that pay more rewards to aspects of research collaboration with researchers outside the cluster.

The research trend of biodiesel topics in Indonesia were analyzed with topic modeling using LLDA (Ramage, Hall, Nallapati, \& Manning, 2009) and co-word analysis using VOSViewer as a visualisation tool. The data training method in topic modeling used the collapsed variational Bayes approximation to the LDA (Teh et al., 2006). The dataset used for the purpose of topic modeling was Scopus indexed publication from 2000 until May 2019. For the purpose of viewing the latest trend, the time range was extended to current date. Usually, the selected model from different values of the number of topics $(\mathrm{k})$ is set for the lowest perplexity score, which is in our case $\mathrm{k}=50$, that marks the global minimum of the perplexity curve. However, for the purpose of meaningful explanation, we chose the highest perplexity score of $\mathrm{k}=25$. Picking another low perplexity score by $\mathrm{k}=10$ provides too little information for the analysis. The topics from the results are shown in Table 3 with a sequence of the top 20 terms that form a topic beginning with the most important one. Topic 01, topic 03 , topic 04 , topic 10 , topic 15 , and topic 18 were regarding feedstocks used in biodiesel production, e.g. Trisperma reutealis, Innophyllum calophyllum, Pongamia pinnata, Chlorella vulgaris \& Nannochloropsis oculata, Sterculia foetida, and Jatropha curcas respectively. Topic 18 is about developing biodiesel with Jatropha curcas whereby the topic trend over the years is shown in Figure 7(d). Jatropha curcas had been a hot topic in Indonesia since the year 2006 as an alternative feedstock for biodiesel and currently Indonesia is using it for biodiesel production besides oil palm. Silitonga, Atabani, Mahlia, Masjuki, Badruddin, and Mekhilef (2011) found out that the production of biodiesel from Jatropha curcas offers many social, economical, and environmental benefits for the country. Nevertheles, they did not use Jatropha curcas as a raw material in the research because they did not see the certainty in the policy ensuring availability as a raw material, instead she focused on using seeds of $C$. inophyllum. From the view of a life cycle assesment, the development of biodiesel production based on $J$. curcas is not competitive because the identified inefficiency in the transportation, low productivity in the cultivation and the green house gas (GHG) emission from the use of fertilizer (Fuentes, García, Hennecke, \& Masera, 2018). There is a need for in-depth analysis carried out in Indonesia before developing projects related to $J$. curcas based biodiesel production. 


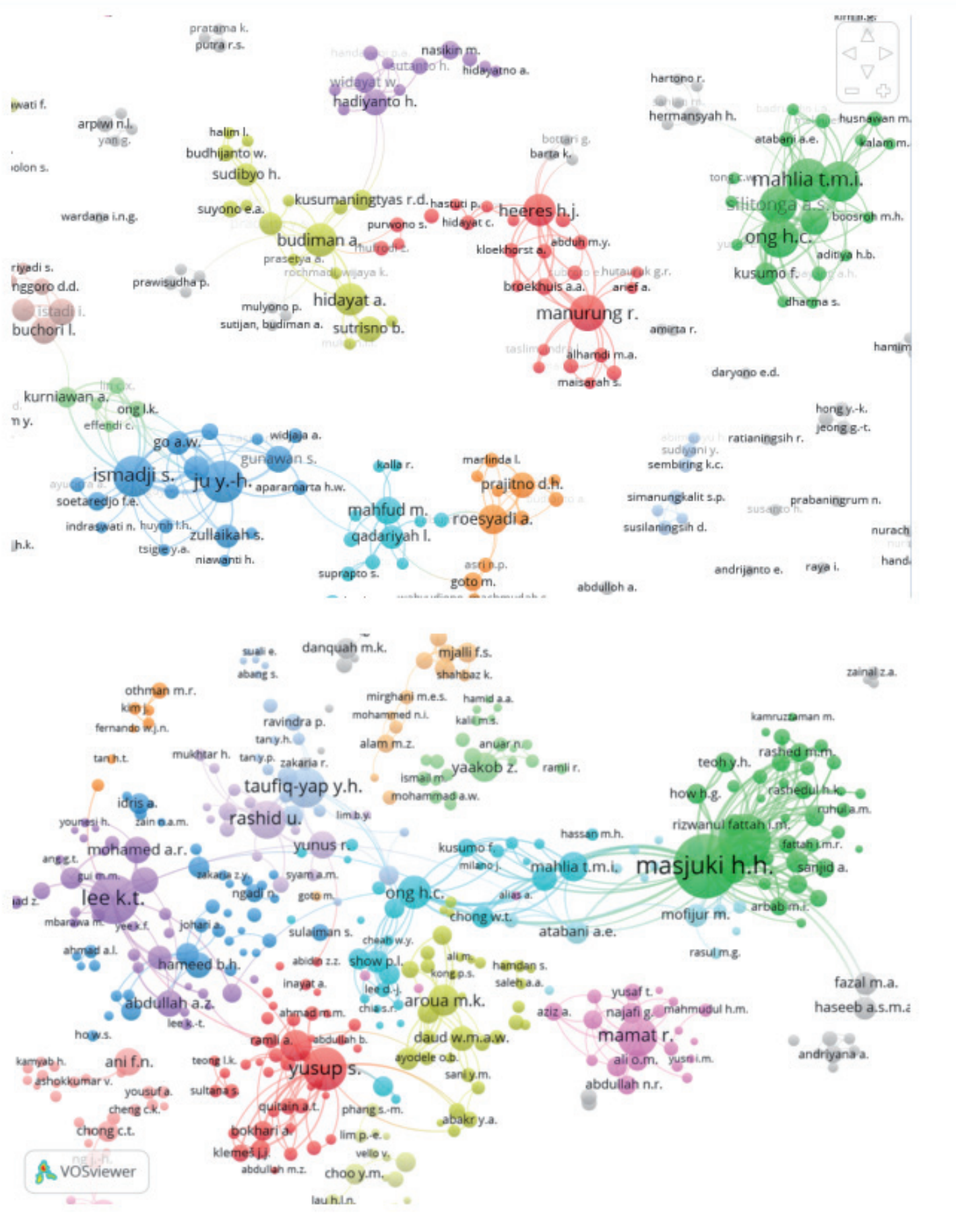

Figure 6. The Comparison between Indonesian (above) and Malaysian (under) Citation on Biodiesel Publication in Scopus 
Table 2. Topic Modeling of the Indonesian Research Topics in Biodiesel

\begin{tabular}{|c|c|}
\hline Topic & Top 20 Terms of the Topic \\
\hline Topic 00 & $\begin{array}{l}\text { reactor fame synthesis plasma voltage hybrid dielectric discharge applied electrolysis effect time catalytic-plasma } \\
\text { performance basicity diameter combined methods enhanced electrode }\end{array}$ \\
\hline Topic 01 & $\begin{array}{l}\text { trisperma growth reutealis plant wastewater treatment kemiri sunan plants root higher corrosion bacteria glycerol } \\
\text { deposits indicated number physiological increase increased }\end{array}$ \\
\hline Topic 02 & $\begin{array}{l}\text { time microwave glycerol ultrasonic supercritical heating assisted power effect ultrasound minutes chitosan irradiation } \\
\text { ratio batch triacetin conventional frequency showed produce }\end{array}$ \\
\hline Topic 03 & $\begin{array}{l}\text { seed inophyllum seeds calophyllumnyamplung rubber extraction cake moisture water quality methods specific } \\
\text { group indonesia size press protein feedstock weight }\end{array}$ \\
\hline Topic 04 & $\begin{array}{l}\text { genetic continuous pongamiapinnata molecular tree trees population flow plant selection diversity based indonesia } \\
\text { applications refining highly scale traits java }\end{array}$ \\
\hline Topic 05 & $\begin{array}{l}\text { combustion characteristics fuels engines boiler emission blends biofuels pressure chamber ignition droplet heat } \\
\text { lower higher ambient gasoline emissions biodiesels properties }\end{array}$ \\
\hline Topic 06 & $\begin{array}{l}\text { model data reactive distillation kinetic experimental column simulation product models reactor continuous order } \\
\text { pressure developed vegetable artificial predict adsorption feed }\end{array}$ \\
\hline Topic 07 & $\begin{array}{l}\text { ratio optimum time conditions optimization parameters response surface methodology value properties respectively } \\
\text { molar speed design variables based experimental pentandra analysis }\end{array}$ \\
\hline Topic 08 & $\begin{array}{l}\text { pome water reactor effluent mill anaerobic substrate media batch addition zeolite inoculum digestion solution } \\
\text { reactors } \mathrm{mg} / \mathrm{l} \text { hydrolysis natural biogas plastic }\end{array}$ \\
\hline Topic 09 & $\begin{array}{l}\text { lipase enzyme activity fermentation immobilized substrate solid immobilization showed synthesis highest aspergillus } \\
\text { state produced interesterification resin unit analysis protein gene }\end{array}$ \\
\hline Topic 10 & $\begin{array}{l}\text { microalgae lipid extraction biomass medium cell chlorella cultivation vulgaris growth algae species culture nan- } \\
\text { nochloropsis lipids highest source solvent feedstock productivity }\end{array}$ \\
\hline Topic 11 & $\begin{array}{l}\text { performance blends consumption emissions exhaust efficiency spray injection specific thermal blend power } \\
\text { compared experimental brake cerbera emission effect compression biodiesel-diesel }\end{array}$ \\
\hline Topic 12 & $\begin{array}{l}\text { system cost price chain plant supply model order cycle life value operational proposed bio-diesel industry problem } \\
\text { technology design total conducted }\end{array}$ \\
\hline Topic 13 & $\begin{array}{l}\text { species biomass oleaginous environmental emissions emission yeast yeasts crude utilization bioenergy sector biogas } \\
\text { industrial management total sustainable including lipids electricity }\end{array}$ \\
\hline Topic 14 & $\begin{array}{l}\text { ratio rice time esterification bran crude free fame work mole condition situ amount subcritical step carried optimum } \\
\text { varied conditions acetic }\end{array}$ \\
\hline Topic 15 & $\begin{array}{l}\text { cooking coconut liquid product esters biofuel catalytic cracking produced mixture value free products sterculia } \\
\text { carried foetida composition fuels synthesis chain }\end{array}$ \\
\hline Topic 16 & $\begin{array}{l}\text { glycerol ratio solvent molar ethanol purification stirring produced water highest co-solvent time speed separation } \\
\text { deep eutectic chloride ethyl purity k2co3 }\end{array}$ \\
\hline Topic 17 & $\begin{array}{l}\text { catalysts heterogeneous solid zeolite showed activity analysis prepared natural ratio synthesis ftir preparation husk } \\
\text { calcination surface characterized oxide synthesized impregnation }\end{array}$ \\
\hline Topic 18 & $\begin{array}{l}\text { curcas alternative oils renewable vegetable paper fossil non-edible development environmental edible sources } \\
\text { review produced source methods feedstocks fuels problems animal }\end{array}$ \\
\hline Topic 19 & $\begin{array}{l}\text { higher membrane performance rate catalytic found increasing effect respectively diameter surface total various } \\
\text { improved resulting moreover pore techniques volume soybean }\end{array}$ \\
\hline Topic 20 & $\begin{array}{l}\text { carbon filter systems dioxide steel emissions wear level ability change indicated thus reducing result machine } \\
\text { reduces conducted application shows positive }\end{array}$ \\
\hline Topic 21 & $\begin{array}{l}\text { stability oxidation antioxidant hydrogenation value storage additives increase additive period commercial pyrogallol } \\
\text { addition oxidative quality test viscosity antioxidants mixture product }\end{array}$ \\
\hline Topic 22 & $\begin{array}{l}\text { acids esterification free oleic respectively molar activation pfad esters studied kinetics oils palmitic conditions } \\
\text { increased reactions temperatures determined saturated zirconia }\end{array}$ \\
\hline Topic 23 & $\begin{array}{l}\text { indonesia demand development food feedstock policy government increase products system scenario increased } \\
\text { year indonesian develop analysis scenarios material meet crude }\end{array}$ \\
\hline Topic 24 & $\begin{array}{l}\text { viscosity density point properties number value physical esterification standard test variation result kinemat } \\
\text { synthesis product flash astm hours analysis based }\end{array}$ \\
\hline
\end{tabular}


Figure 7 depicts the sample of topic trend results from topic modeling, whereby each topic slightly shows different trend initiation. Figure 7a shows the topic 05 on the testing of the combustion engine characteristics of the used biodiesel. This topic has been much investigated since 2005 with the up and down intensities over the year. The topic seems to be concerned more on the emission. The palm oil mill effluent or POME topic (topic 08) as shown in Figure 7b shows a high interest lately (from the year 2013) as new installation of POME plants are initiated in Indonesia. Topic 10 is the topic on microalgae as feedstock for the biodiesel production with species of Chlorella vulgaris and Nannochloropsis oculata, and it is concerning on the cultivation, lipid extraction, and the productivity. Among the four sample topics, the topic on microalgae was the hottest topic (Figure 7). In Indonesia, research on microalgae was initiated about ten years ago, but only after 2015 it begun having a high intensity (Figure 7c). The trend is in alignment with world trend on transiting to a low carbon economy through third-generation biofuels based on microalge. Microalgae fuels are not commercial yet, but the economy outlook is promising (Bajpai, 2019). Microalgae nowdays is viewed as a third-generation biofuel due its high (annual) surface biomass productivity, efficient conversion of solar energy into chemical energy and the ability to grow on non-agricultural land (Li-Beisson \& Peltier, 2013).

Figure 8 shows the network of keywords as a result of the co-word analysis using VOSViewer. There are several concepts that were similar with the results of topic modeling, such as topic on DES (Deep Eutectic Solvent) in extraction process, topic cluster on microalgae as feedstock, topic on the combustion characteristics in diesel engine, and the waste treatment in POME installation. The results from the visualisation technique showed some coherence with the results from the topic modeling, and these were triangulated in concluding the findings. While Figure 8 shows the clustering and terms importance in the cluster, the topic modeling in Figure 7 showed the trend

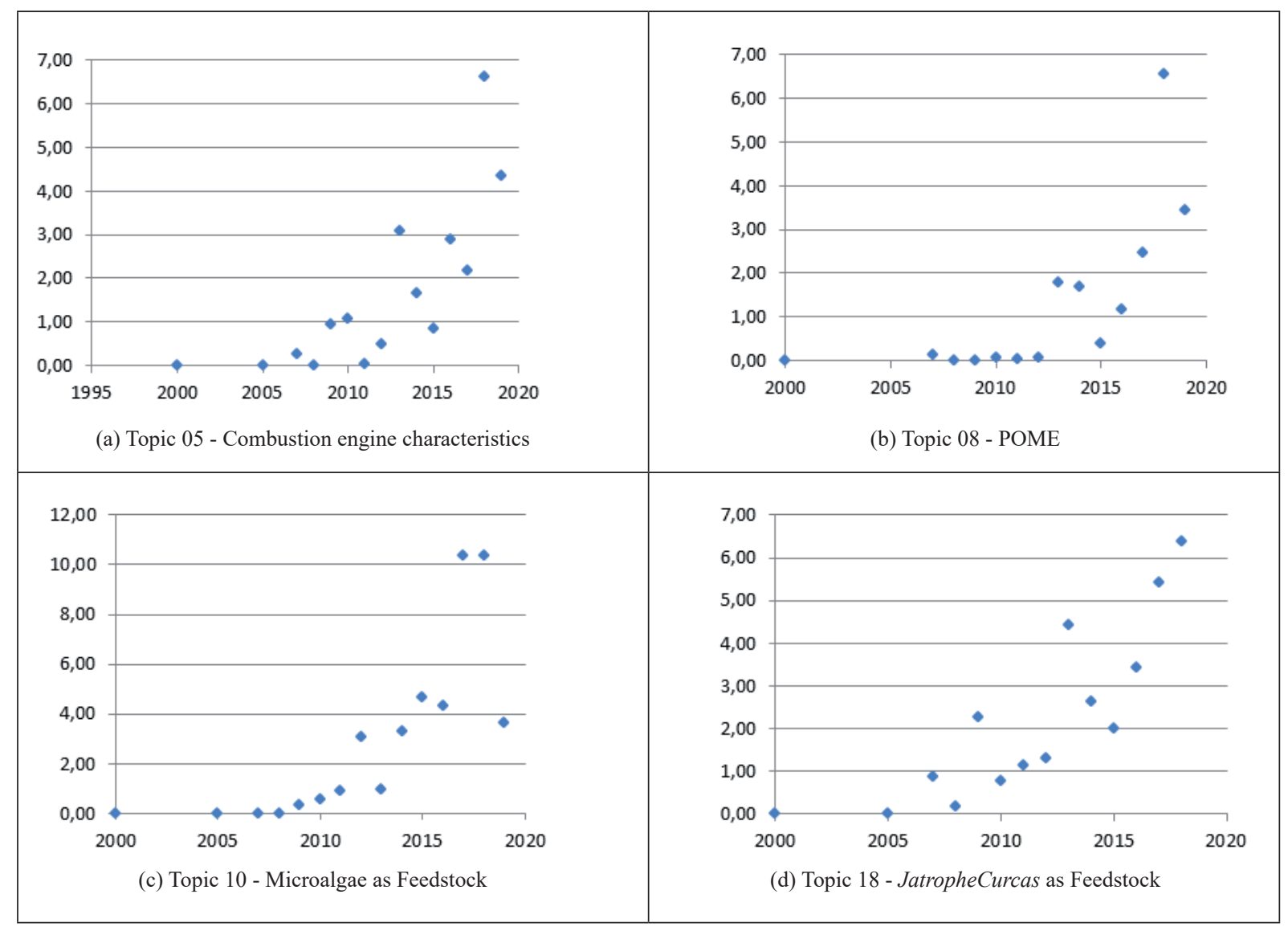

Figure 7. Sample Topics and the Trends of Results from Topic Modeling 
of the topic. This trend information is important in predicting the future landscape of the technology where the profile of topic on microalgae showed the growth and the importance of this topic in the future (Figure 7).

\section{Meso Level Analysis}

At the institutional level, there are various anomalies in the publications produced (Figure 9). The far greater impact (number of citations) was produced by the Politeknik Negeri Medan in the Indonesian biodiesel publications although it is not in the top 10 best universities in Indonesia.
While Institut Teknologi Sepuluh Nopember (ITS) has the highest productivity (61), since 2016 it has lagged behind in the impact of publications of Gadjah Mada University (UGM), which has significantly developed its publication's citations. At the first thought, this can be regarded as a proxy to represent better quality of the UGM's publications. Upon rigorous investigation there should be an accurate explanation of this citation burst for example by way of in-depth interview which is not the case and/or using other metrics. In-depth investigation is especially needed for the case of much higher publication citation of Politeknik Negeri Medan.

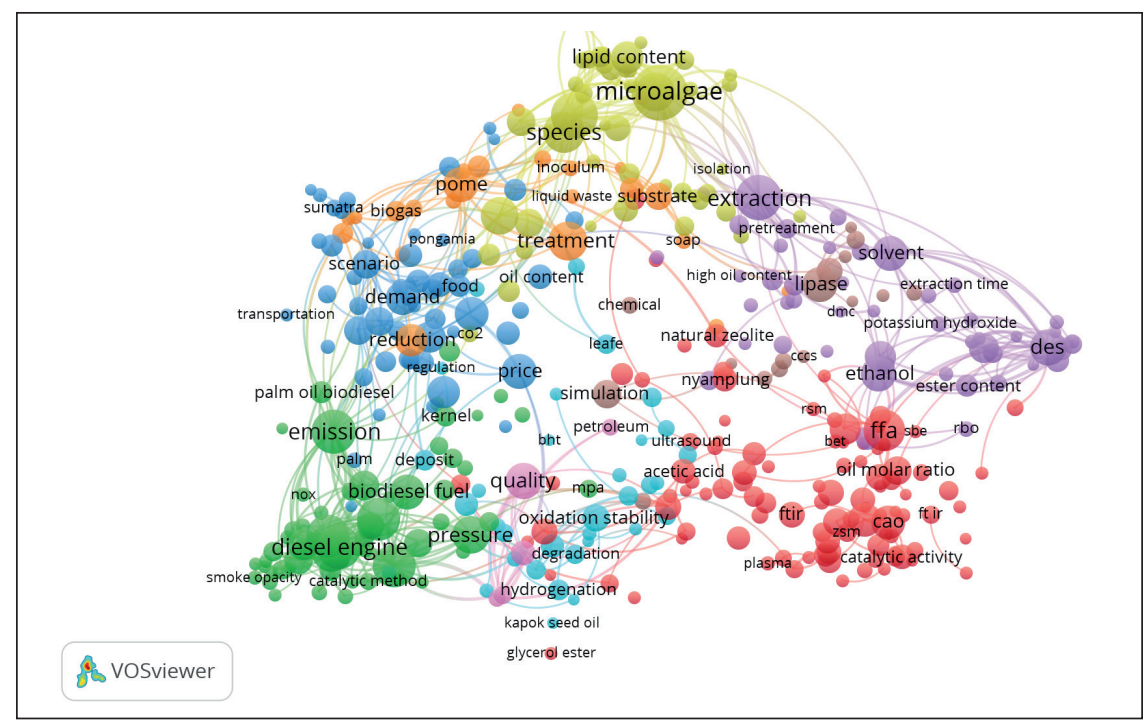

Figure 8. Results from Topic Mapping with Co-word Using VOSViewer

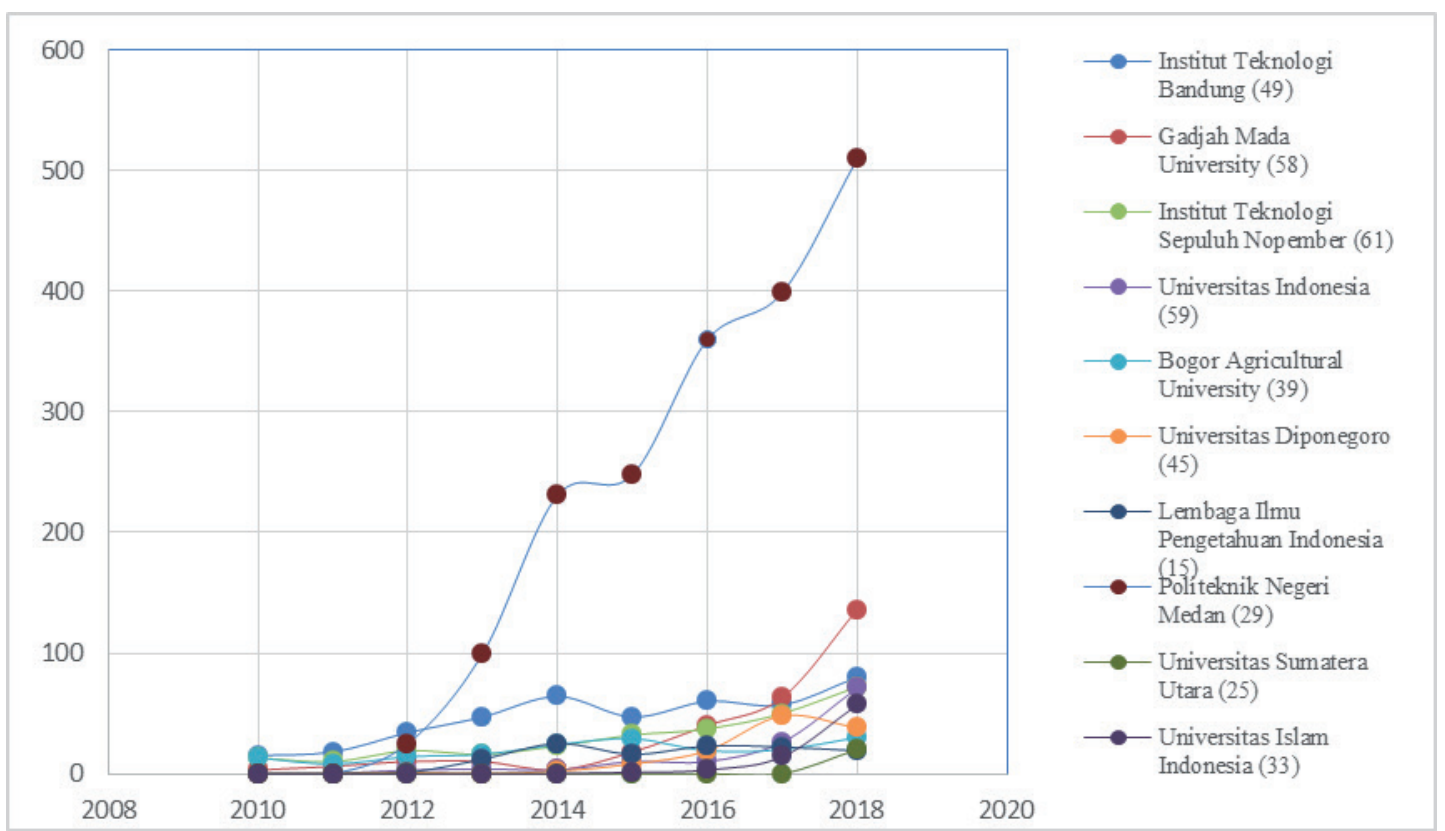

Figure 9. Impact of Institutional Biodesel Publication in Indonesia 
Tabel 3 shows the analysis from the total value of aggregation and aggregate $h$-index values based on biodiesel publications. Politeknik Negeri Medan is still scoring the highest (2228, h-index $=20$ ). From the h-index evaluation point of view, ITB (h-index $=10$ ) competes well among the top five universities (ITB, UGM, ITS, UI, and IPB), but the top five's citations are far less than Politeknik Negeri Medan. There is no kind of a super productive researcher within these top five universities. The high citation score of Politeknik Negeri Medan is contributed significantly from Silitonga, a kind of an outlier. Tabel 3 also shows that the total number of citations of the top five universities (column 2) is much higher than the measured citation counts from the year 2000 until

Table 3. Total Citation and Document h-index of Institutional Publications in Biodiesel

\begin{tabular}{lcc}
\hline \multicolumn{1}{c}{ Institute } & $\begin{array}{c}\text { Total } \\
\text { Citation }\end{array}$ & $\begin{array}{c}\text { Document } \\
\text { h-index }\end{array}$ \\
\hline Institut Teknologi Bandung (49) & 452 & 10 \\
\hline Gadjah Mada University (58) & 332 & 9 \\
\hline Institut Teknologi Sepuluh & 307 & 9 \\
Nopember (61) & 157 & 7 \\
\hline Universitas Indonesia (59) & 188 & 8 \\
\hline Bogor Agricultural University (39) & 134 & 6 \\
\hline Universitas Diponegoro (45) & 132 & 5 \\
\hline $\begin{array}{l}\text { Lembaga IImu Pengetahuan } \\
\text { Indonesia (15) }\end{array}$ & 2228 & 20 \\
\hline Politeknik Negeri Medan (29) & 77 & 3 \\
\hline Universitas Sumatera Utara (25) & 57 & 5 \\
\hline Universitas Islam Indonesia (33) & & 5 \\
\hline
\end{tabular}

2018. This reveals that the longtime trajectories of the research in these institutions do not influence too much the current performance of the institution.

In international collaboration context, Malaysia has taken a prominent involvement in research collaboration in Indonesia (Figure 10). Malaysia's involvement in Indonesia is mainly due to the intense research collaboration with Politeknik Negeri Medan with a total number of 32 in the country co-authorship and this collaboration development is increasing year by year. Figure 10 shows the international collaboration in Indonesia biodiesel publications. On the bar chart the left bar represents the number of publications of an institution and the right bar represents the total number all countries co-authorship (collaboration) in the publications.

Among the top five institutions productivity on biodiesel publication, ITB has the highest proportion of international collaboration in its publications and respectively followed by ITS, IPB, UGM, and UI. The biggest contribution of international collaboration in ITB's research publication is from Netherland (13) and Japan (7). They have also the largest contribution to UGM's publications, 3 and 4 publications respectively, while the biggest portion of international collaboration in the publication of ITS's research is with Taiwan (11). Besides with Politeknik Negeri Medan, Malaysia (22) has also high contribution within the Syiah Kuala University's publications.

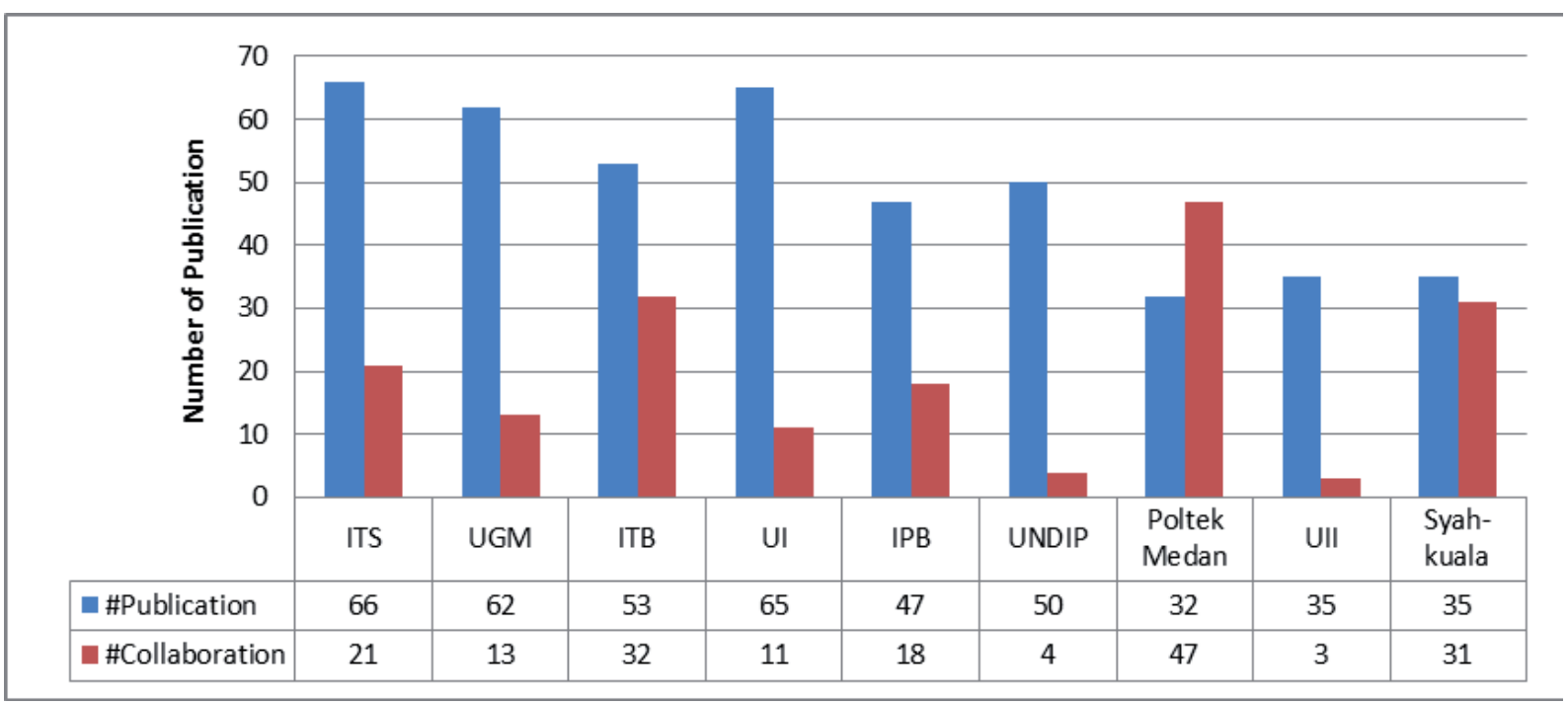

Figure 10. Institutional Productivity and International Colaboration in Biodiesel 


\section{Micro Level Analysis}

Silitonga and Manurung are prominent producers in the biodiesel publication network in Scopus. The top part of Figure 6 shows how the large producers are organized into nine groups, two of which are not connected. Unfortunately, the connection in biodiesel publication network is not built by these two large producers. They do not play a very important role in the network, as they do not act as bridges connecting the other clusters which are still seemed isolated. In other word, they are not so influencial, even though they are in a dense cluster (with high clustering coefficients). The central role of Silitonga in social network of Indonesian biodiesel publications needs to be pursued considering her h-index is very high compared to the others (h-index $=20$ ).

The comparison between the top two researchers in Indonesia and Malaysia shows how the level of collaboration of researchers in Malaysia is quite high and has entered the level of world class (Table 4). In Indonesia, Siltonga is included in the world class researcher ranks, but she is still a rare case in Indonesia. Her degree of centrality (the capacity to communicate directly with others) is about the same as with the Malaysian top performer. Nevertheless, she has less connection with others in the Indonesian social network (kind of isolated) as visually depicted in Figure 6. She has also about the same capacity to reach many of the other members of the network directly without relying on intermediaries, as the two Malaysian top researchers shown in the closeness centrality column. Among the four

Table 4. The Comparison between Top Two Biodiesel Researchers in Indonesia and Malaysia

\begin{tabular}{ccccc}
\hline Country & Name & $\begin{array}{c}\text { Degree } \\
\text { Cen- } \\
\text { trality }\end{array}$ & $\begin{array}{c}\text { Closeness } \\
\text { Centrality }\end{array}$ & $\begin{array}{c}\text { Between- } \\
\text { ness } \\
\text { Centrality }\end{array}$ \\
\hline Indonesia & $\begin{array}{l}\text { A.S. } \\
\text { Silitonga }\end{array}$ & 126 & 2053 & 76.333 \\
\hline & $\begin{array}{l}\text { Renita } \\
\text { Manurung }\end{array}$ & 36 & 2220 & 94.233 \\
\hline Malaysia & Malia & 120 & 2052 & 90.531 \\
\hline & Masjuki & 118 & 2053 & 72.697 \\
\hline
\end{tabular}

researchers, Manurung has the highest relationship centrality which refers to the control she exerts over communication between others and her capacity to restrict it.

In Figure 6, it can be seen that Manurung looks very productive in the red cluster, while Silitonga looks to have greater productivity in the green clusters. Silitonga is a researcher from Politeknik Negeri Medan who has high productivity and high impact in the publication of the biodiesel $($ h-index $=20, \#$ docs $=29, \#$ citation $=2228)$ (Figure 11). In the laboratory where she worked, there are 5 human resources, 3 of them have doctoral degree. The research network that was formed includes Syiah Kuala University in Banda Aceh and University of Malaya, with Malia (her promotor) and Masjuki. High h-index and high impact in Scopus give another benefit as she got 438 million Indonesian rupiahs in rewards from Indonesian government. This appreciation gives her new enthusiasm in further doing research. Her publication citations are around 2000 and are ranked second in Sinta index. Her research topic is on raw material processing related to acid value and viscosity. To this end she started from simple and easy research like using palm oil. The glycerol topic in biodiesel research is not conducted because this is more a chemical technique which is not her educational background. The difference with research in Chemical Engineering Faculty of Universitas Sumatera Utara is her topic is not focused and very diverse. On the topic of microalgae as feedstock, she focused on how to make a new method where only chlorophyl is discarded, but this research topic is still pending, instead she prefered other non-edible plants, which technology is mature enough like Canophylum inophylum and Jatropha curcas. She is now no longer working on Jatropha curcas. Her research progressed to innovation in creating new methods with a focus on non-edible raw materials. To this end, new equipment was made by herself in order to submit a patent. The equipment purchased from the manufacturer was then modified (for example by adding ultrasonic wave generator and high-pressure device). The result is a patent application equipment prototype. 
Manurung is a researcher from Universitas Sumatera Utara who has prominent publication productivity in the biodiesel field (h-index = 3 , $\#$ doc $=13$, \#citation = 14). Her research is focused on a topic called Deep Eutectic Solvent (DES) (Figure 11). This technique is used in the biodiesel production based on palm oil. DES research topics (in topic modeling emerges as topic 16) can be seen visually in co-word analysis using VOSViewer as in Figure 8 located at the right side. Figure 11 shows trends in the development of DES topics obtained through topic modeling, while Figure $7 \mathrm{~b}$ shows another alternative (a competing technology) in biodiesel production using a supercritical methanol transesterification for higher efficiency and rapid process. This method is of interest because it allows processors to make use of low-cost feedstock (Wasiak, 2019).

Silitonga has also pursued this effort in her laboratory. The process can be run at a lower temperature, thereby reducing the need to heat the reaction mixture and saving considerable energy. Then, the process is assisted with a microwave or ultrasound device. This explanation is an interpretation of topic 02 (Table 2). From the view of future technological change, Figure 7 shows the preference to the technology using DES in the biodiesel production rather than the supercritical transesterification as the trend to growth is higher for DES, although the supercritical process technology shows earlier growth in the trend (around three years earlier).

Manurung started researching biodiesel in 2004 by trying to produce biodiesel in ethyl esther compounds which at that time were less desirable in large-scale biodiesel production. They are more difficult to purify and produce ethanol compounds that are less reactive than methanol, but the advantage is in the heat content. Later on, she made biodiesel using $\mathrm{KOH}$ as catalyst to replace the $\mathrm{NaOH}$ from a continuous batch proces. The results were not very good due to equipment constraints. In 2013, she researched enzymatic processes for her doctoral study. These were conducted because the production of biodiesel still leaves the used catalyst which is difficult to remove from a mixture of liquid waste (not environmentally friendly as is claimed). The enzymatic process is not a prefered alternative because it is expensive and immobilized. This concern is depicted in topic modeling, as topic 09, in case of using lipaseenzyme (Table 2). DES was eventually applied using glycerol because the previously used ionic liquid was expensive and toxic. It was applied near the end of the reaction. It resulted in a low-density product and good viscosity for biodiesel. DES is also applied in collaboration with PT. Wilmar in Dumai for industrial purpose, to solve a problem of a high salt content in the production of biodiesel that hinders export. The solution worked with another benefit reducing the use of water for washing.

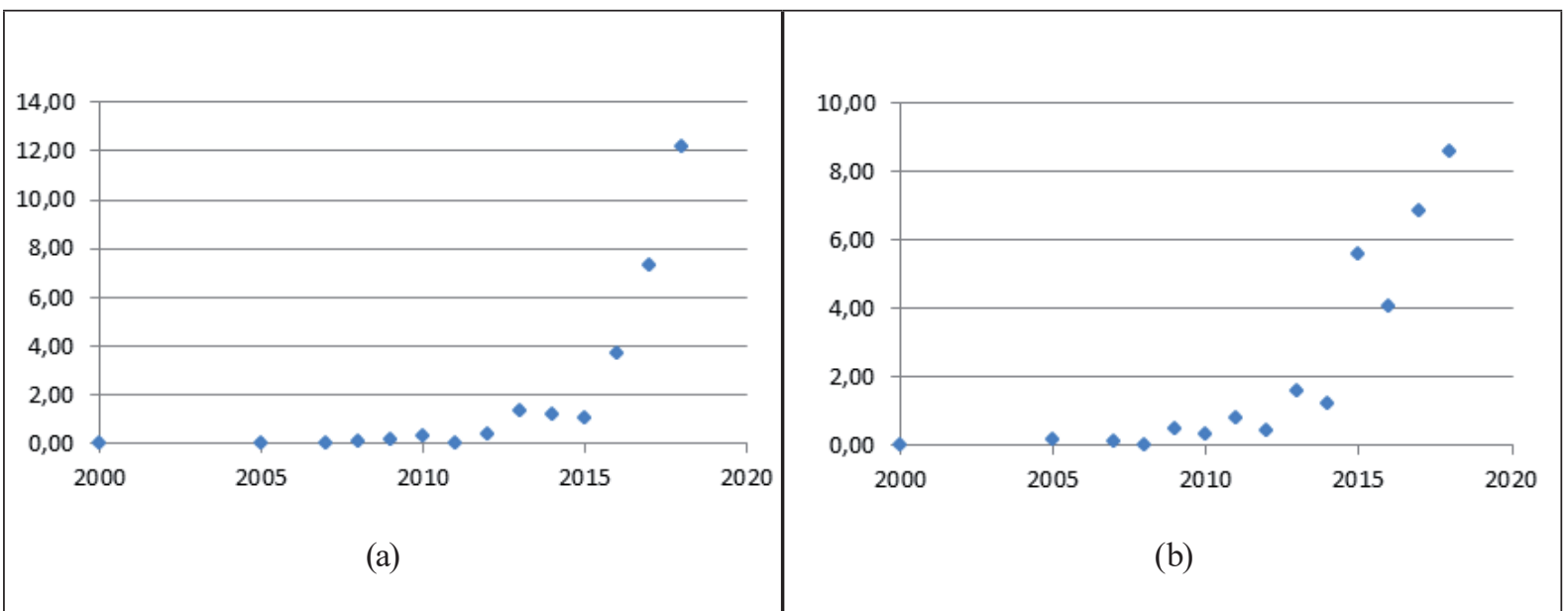

Figure 11. Topic 16: DES (Deep Eutectic Solvent) with Its Trend (a) and An Alternatieve (A Competing) Supercritical Technology in Biodiesel (b) 


\section{E. CONCLUSION}

The study of science and technology measurement based on evidence is very important to be conducted to encourage the making of accurate and effective policies. Our investigation shows an example of the existence of a world-class biodiesel researcher (Silitonga) in Indonesia who is not supported effectively to pursue her central role in collaboration network of Indonesian biodiesel researches. To conduct a deep and comprehensive study, it is necessary to use a mixed method in the scientometric study through triangulation of the results of quantitative data analysis with qualitative data analysis. There is some coherence in quantitative data analysis using various techniques in order to get insight into the conduct of research in biodiesel in Indonesia. The results from the content analysis and in-depth interviews provided a rich picture of the phenomenon studied based on evidence. Results from the scientometric study based on content analysis combined with bibliometric analysis of Indonesian biodiesel research publications show

1. low collaborative research between clusters in Indonesian biodiesel research network,

2. existence of world-class researcher (Silitonga) who are still isolated only in her cluster while pursuing a central role in the collaboration network would be advantageous,

3. the need to improve the quality of Indonesian research in the field of biodiesel because of the low impact of research outputs,

4. some alignments between the research topics to renewable energy using the local natural resources, while also pursuing topic researches on future technological development, and

5. the need for in-depth study of the research topics conducted in biodiesel both in terms of government policy, urgency, strategic value, and sustainability.

\section{ACKNOWLEDGEMENTS}

We thank Dr. Maxensius Tri Sambodo for valuable advices and time for discussion.

\section{Declaration of Conflicting Interests}

The qualitative data used for this report is gained during the investigation in 2018 within the P2KMI-LIPI programme on scientometric study,and the authors declare that there is no conflict of interest.

\section{LITERATURE}

Amara, N. \& Landry, R. (2012). Counting citations in the field of business and management: Why use Google Scholar rather than the Web of Science. Scientometrics, 93(3), 553-581. DOI: 10.1007/ s11192-012-0729-2.

Bajpai, P. (2019). Third Generation Biofuels. Singapore: Springer Singapore.

Blei, D. M. (2012). Probabilistic topic models. Communications of the ACM, 55(4), 77-84. DOI: $10.1145 / 2133806.2133826$.

Blei, D. M., Ng, A. Y., \& Jordan, M. I. (2003). Latent dirichlet allocation. Journal of Machine Learning Research, 3(Jan), 993-1022.

Chang, J., Gerrish, S., Wang, C., Boyd-graber, J. L., \& Blei, D. M. (2009). Reading tea leaves: How humans interpret topic models. In Advances in neural in-formation processing systems 21 (NIPS-09), 288-296. Vancouver, Canada: Neural Information Processing Systems Foundation, Inc.

Costin-Gabriel, C., \& Rebedea, T. E. (2014). Archaisms and neologisms identification in texts. In RoEduNet Conference 13th Edition: Networking in Education and Research Joint Event RENAM 8th Conference (1-6). Piscataway, New Jersey, USA: IEEE.

de Souza, L. G. A., de Morales, M. A. F. D., Poz, M. E. S. D., \& da Silveira, J. M. F. J. (2015). Collaborative networks as a measure of the innovation systems in second-generation ethanol. Scientometrics, 103(2), 355-372. https:// doi.org/10.1007/s11192-015-1553-2.

Freeman, L. C. (1978/79). Centrality in social networks: Conceptual clarification. Social Networks, 1(3), 215-239.

Fuentes, A., García, C., Hennecke, A., \& Masera, O. (2018). Life cycle assessment of Jatropha curcas biodiesel production: A case study in Mexico. Clean Technologies and Environmental Policy, 20(7), 1721-1733. https://doi. org/10.1007/s10098-018-1558-7.

Hardiyati, R., Nadhiroh, I. M., Handayani, T., Silalahi, V. M. M., Rahmaida, R., \& Amelia, M. (2018). A contextual scientometric analysis of Indonesian biomedicine: Mapping the potential of basic research downstreaming. STI 
Policy and Management Journal, 3(1), 67-80. DOI: $10.14203 /$ STIPM.2018.134.

Hirsch, J. E. (2005). An index to quantify an individual's scientific research output. Proceedings of the National Academy of Sciences, 102(46), 16569-16572.

Ho, Y. S. (2018). Comments on "Past, current and future of biomass energy research: A bibliometric analysis" by Mao et al. (2015). Renewable and Sustainable Energy Reviews, 82, 4235-4237. DOI: https://doi.org/10.1016/j. rser.2017.04.120.

Larsen, P. (2008). The state of the art in publication counting. Scientometrics, 77(2), 235-251. DOI: $10.1007 / \mathrm{s} 11192-007-1991-6$.

Li-Beisson, Y. \& Peltier, G. (2013). Third-generation biofuels: current and future research on microalgal lipid biotechnology. OCL, 20(6). DOI: https://doi.org/10.1051/ocl/2013031.

MacRoberts, M. \& MacRoberts, B. (1996). Problems of citation analysis. Scientometrics, 36(3).

Manning, C. D., Raghavan, P., \& Schütze, H. (2007). Introduction to information retrieval. Cambridge: Cambridge University Press.

Mao, G., Zou, H., Chen, G., Du, H., \& Zuo, J. (2015). Past, current and future of biomass energy research: A bibliometric analysis. Renewable and Sustainable Energy Reviews, 52(December), 1823-1833. https://doi.org/10.1016/j. rser.2015.07.141.

Ramage, D., Hall, D., Nallapati, R., \& Manning, C. D. (2009). Labeled LDA: A supervised topic model for credit attribution in multi-labeled corpora. In Proceedings of the 2009 conference on empirical methods in natural language processing (248-256). Stroudsburg, Pennsylvania, USA: Association for Computational Linguistics.

REN21. (2015). Renewables 2015 global status report. Retrieved from http://www.ren 21. net/wp-content/uploads/2015/07/REN12GSR2015_Onlinebook_low1.pdf.

REN21. (2018). Renewables 2018 global status report. Retrieved from https:/www.ren21.net/ wp-content/uploads/2019/05/GSR2018_FullReport_English.pdf.

Sambodo, M. T., Morohosi, H., \& Oyama, T. (2016). Developing a green path power expansion plan in Indonesia by applying a multiobjective optimization modeling technique. Journal of Energy Engineering, 143(3).

Silalahi, M., Hardiyati, R., Nadhiroh, I. M., Handayani, T., Amelia, M., \& Rahmaida, R. (2018). A text classification on the downstreaming potential of biomedicine publications in Indonesia. In Proceeding 2018 International Conference on Information and Communications Technology (ICOIACT) (515-519). Piscataway, New Jersey, USA: IEEE.

Silalahi, V. M. M., Hardiyati, R., Nadhiroh, I. M., Handayani, T., Rahmaida, R., \& Amelia, M. (2018). A framework for text mining in scientometric study: A case study in biomedicine publications. Journal of Physics: Conference Series, 1007(1).

Silitonga, A. S., Atabani, A. E., Mahlia, T. M. I., Masjuki, H. H., Badruddin, I. A., \& Mekhilef, S. (2011). A review on prospect of Jatropha curcas for biodiesel in Indonesia. Renewable and Sustainable Energy Reviews, 15(8), 3733-3756.

Sitarz, R. (2013). Identification of research trends in the field of separation processes. application of epidemiological model, citation analysis, text mining, and technical analysis of the financial markets (Doctoral thesis, Lappeenranta University of Technology, Lappeenranta, Finland). Retrieved from http://lutpub.lut.fi/bitstream/ handle/10024/93330/isbn9789522654847. pdf?sequence $=2$.

Teh, Y. W., Newman, D., \& Welling, M. (2006). A collapsed variational Bayesian inference algorithm for latent Dirichlet allocation. In Advances in neural information processing systems 19 (NIPS-06) (1353-1360). Vancouver, Canada: Neural Information Processing Systems Foundation, Inc.

Tsai, H. H. (2011). Research trends analysis by comparing data mining and customer relationship management through bibliometric methodology. Scientometrics, 87(3), 425-450. DOI: 10.1007/s11192-011-0353-6

van Raan, A. F. J. (1997). Scientometrics: State-of-theart. Scientometrics, 38(1), 205-218.

van Raan, A. F. J. (2014). Advances in bibliometric analysis: Research performance assessment and science mapping. London: Portland Press Limited.

Wasiak, A. L. (2019). Technologies of biofuel production. In Modeling Energetic Efficiency of Biofuels Production (29-34). Switzerland: Springer International Publishing.

Zhao, W., Chen, J. J., Perkins, R., Liu, Z., Ge, W., Ding, Y., \& Zou, W. (2015). A heuristic approach to determine an appropriate number of topics in topic modeling. BMC Bioinformatics, 16(Suppl13). DOI: 10.1186/1471-2105-16-S13-S8. 